\title{
Protease Activated Receptor-1 (PAR-1) Mediated Platelet Aggregation is Dependant on Clopidogrel Response
}

\author{
Rolf P. Kreutz, MD1),2), Jeffrey A. Breall, MD, PhD'), Yvonne Kreutz, MS'), Janelle Owens, \\ BS $^{2)}$, Deshun Lu, PhD'), Islam Bolad, MBBS, MD'), Elisabeth von der Lohe, MD'), Anjan \\ Sinha, MD ${ }^{1)}$, and David A. Flockhart, MD, PhD ${ }^{2}$ ) \\ 1)Krannert Institute of Cardiology, Indiana University School of Medicine, Indianapolis \\ 2)Division of Clinical Pharmacology, Indiana University School of Medicine, Indianapolis
}

\section{Abstract}

Introduction-Clopidogrel inhibits ADP mediated platelet aggregation through inhibition of the P2Y12 receptor by its active metabolite. Thrombin induces platelet aggregation by binding to protease activated receptor-1 (PAR-1), and inhibition of PAR-1 has been evaluated in patients treated with clopidogrel to reduce ischemic events after acute coronary syndromes. Residual PAR-1 mediated platelet aggregation may be dependent on extent of clopidogrel response.

Material and Methods-Platelet aggregation was measured in 55 patients undergoing elective $\mathrm{PCI}$ at $16-24$ hours after $600 \mathrm{mg}$ clopidogrel loading dose by light transmittance aggregometry using ADP $20 \mu \mathrm{M}$ and thrombin receptor agonist peptide (TRAP) at $15 \mu \mathrm{M}$ and $25 \mu \mathrm{M}$ as agonists. Genomic DNA was genotyped for common CYP2C19 variants.

Results-Increasing quartiles of $20 \mu \mathrm{M}$ ADP induced platelet aggregation after clopidogrel loading were associated with increasing levels of TRAP mediated platelet aggregation. Patients in the highest quartile (clopidogrel non-responders) of post treatment ADP aggregation had significantly higher TRAP mediated aggregation than the patients in the lowest quartile (clopidogrel responders) [TRAP $15 \mu \mathrm{M}: 79.6 \pm 5 \%$ vs. $69.5 \pm 8 \%, \mathrm{p}<0.001$ ].

Conclusions-Non-responders to clopidogrel show increased residual platelet aggregation induced by TRAP, whereas clopidogrel responders exhibit attenuated response to TRAP. Addition of PAR-1 antiplatelet drugs may be most effective in patients with reduced clopidogrel response and high residual TRAP mediated platelet aggregation.

\section{Keywords}

Platelet; clopidogrel; aggregation; thrombin

\footnotetext{
(C) 2012 Elsevier Ltd. All rights reserved.
}

Corresponding Author: Rolf P. Kreutz, MD Assistant Professor of Clinical Medicine Krannert Institute of Cardiology \& Division of Clinical Pharmacology Indiana University School of Medicine 1800 N. Capitol Ave, ME-400 Indianapolis, IN 46202 Phone: (317) 9620561 Fax: (317) 9620113 rkreutz@iupui.edu.

Publisher's Disclaimer: This is a PDF file of an unedited manuscript that has been accepted for publication. As a service to our customers we are providing this early version of the manuscript. The manuscript will undergo copyediting, typesetting, and review of the resulting proof before it is published in its final citable form. Please note that during the production process errors may be discovered which could affect the content, and all legal disclaimers that apply to the journal pertain.

Disclosure: The authors have no conflicts of interest to declare. 


\section{INTRODUCTION}

Platelet activation and aggregation are crucial in the genesis of coronary thrombosis and dual antiplatelet therapy with aspirin and clopidogrel are standard of care in the prevention of stent thrombosis after coronary stenting [1]. Interindividual variations of ex-vivo measurements of platelet aggregation during clopidogrel therapy have been correlated to reduced exposure of active clopidogrel thiol metabolite and differences in P2Y12 receptor occupancy [1]. High on treatment platelet reactivity during therapy with clopidogrel and low platelet inhibition are associated with risk of ischemic events after coronary stenting, and in particular stent thrombosis [1-5]. Carriers of cytochrome (CYP) 2C19*2 genetic polymorphism have been shown to have reduced platelet inhibition by clopidogrel and are at increased risk of ischemic events and stent thrombosis after coronary stenting [5-9].

In addition to its key role in regulation of coagulation, thrombin binds to platelets, endothelial cells, leukocytes, fibroblasts, and smooth muscle cells and affects the cellular response to thrombosis [10]. Thrombin binds to and cleaves protease activated receptors (PAR) of which several subtypes have been described, with slightly different roles in animals of different species [11]. In humans, platelets exhibit PAR-1 and PAR-4 receptors, with only minimal expression of PAR-3 [11-13]. However, PAR-1 is the predominant receptor for thrombin mediated platelet activation with an estimated EC50 for thrombin of $\sim 100 \mathrm{pM}$ as compared to $5 \mathrm{nM}$ for PAR-4 [12-14]. Stimulation of platelets by thrombin induces complete and irreversible platelet aggregation in humans, unopposed by platelet P2Y12 receptor inhibition [14-15]. Thrombin receptor agonist peptide (TRAP) selectively binds and acitvates PAR-1 and is used in the point-of-care assay VerifyNow P2Y12 to measure a base platelet aggregation in subjects during therapy with clopidogrel. In combination with ADP induced aggregation, \% platelet inhibition is then calculated by the device [16]. Because of the prominent role of PAR-1 in mediating thrombin induced platelet activation, several PAR-1 inhibitors have been developed for use in patients with coronary artery disease [17-19]. Voraxapar was recently evaluated in patients with acute coronary syndromes who were treated with clopidogrel and aspirin. The trial failed to meet its primary endpoint, with significantly higher rates of bleeding in subjects randomized to voraxapar vs. placebo [18]. Thus, addition of PAR-1 inhibitor to current standard dual antiplatelet therapy is not associated with net clinical benefit based on the primary outcome of the trial. It remains uncertain whether specific benefit could be associated with addition of PAR-1 antagonists in patients with high platelet reactivity on clopidogrel.

The aim of this study was to assess TRAP induced, PAR-1 mediated platelet aggregation in patients on clopidogrel after coronary stenting and examine residual PAR-1 mediated platelet aggregation stratified according to clopidogrel response.

\section{METHODS}

\section{Patients}

The study protocol was approved by the Indiana University institutional review board for research. Informed consent was obtained from all subjects. Subjects were eligible to be enrolled if they were found to have obstructive coronary artery disease on cardiac catheterization and if they received a clopidogrel $600 \mathrm{mg}$ loading dose during a percutaneous coronary intervention (PCI). Subjects were excluded if they had a history of drug or alcohol abuse, pregnancy, bleeding disorder, platelet count less than $150,000 / \mathrm{mm}^{3}$, myelodysplastic or myeloproliferative disorders, coumadin use, chronic liver disease, as well if there was planned glycoprotein IIb/IIIa antagonist use during PCI. 


\section{Blood samples}

A baseline blood sample was obtained from the arterial access sheath prior to administration of clopidogrel loading dose and administration of heparin or bivalrudin in patients not previously exposed to clopidogrel. Peripheral venous blood samples were drawn 16-24 hours after administration of the clopidogrel loading dose. The 16-24 hour sample was used to determine the final on-treatment platelet aggregation used for the primary analysis of platelet aggregation on clopidogrel. All blood samples were directly transferred into vacutainer tubes containing Na-citrate 3.2\% and analyzed within 2 hours.

\section{Platelet aggregation studies}

Ex vivo platelet function was assessed by light transmittance aggregometry (LTA) at $37^{\circ} \mathrm{C}$ with an Optical Lumi-Aggregometer (Model 700 with AggroLink 8 software, Chrono-Log Corporation, Havertown, PA, USA). Platelet rich plasma (PRP) and platelet poor plasma (PPP) were obtained by differential centrifugation as previously described [20,21]. Platelet aggregation in PRP was induced with adenosine diphosphate (ADP) at $20 \mu \mathrm{M}$ and TRAP ((Ser-Phe-Leu-Leu-Arg-Asn), Sigma-Aldrich, MO, USA) at 15 and $25 \mu \mathrm{M}$ final concentration. With the intent to selectively examine the effect of PAR-1 stimulation, TRAP was chosen as platelet aggregation agonist instead of thrombin due to the common difficulty with cleavage of fibrinogen by thrombin and additional clot formation when used in light transmission aggregometry protocols [22]. The choice of concentrations of TRAP used in the assay was based on reports of prior studies. Gremmel et al. studied the value of TRAP in determining a baseline platelet aggregation needed for calculation of $\%$ platelet inhibition in subjects treated with clopidogrel, and used a concentration of $25 \mu \mathrm{M}$ TRAP due to predictable induction of maximal platelet aggregation [23]. We added a lower dose of TRAP at $15 \mu \mathrm{M}$ in order to achieve a slightly submaximal response while maintaining irreversible platelet aggregation above the EC50 concentration of PAR-1 $(\sim 5 \mu \mathrm{M})[12]$.

\section{Genotyping}

Genomic DNA was isolated from whole blood with the aid of Qiagen's QIAamp® DNA Blood Midi Kit (Germantown, MD, USA). Subjects were genotyped for CYP2C19*2 (681G $>A$; rs4244285) and CYP2C19*3 (636G >A; rs4986893) SNPs using a Bio-Rad Laboratories real-time PCR system (iCycler thermal cycler, Bio-Rad Laboratories, USA). Sequence specific primers were used to amplify the alleles of interest, along with two allelespecific TaqMan probes (Applied Biosystems, Foster City, CA, USA). Allelic discrimination was used to determine individual genotypes (Optical System 3.1 software, Bio-Rad Laboratories).

\section{Statistical Analysis}

Statistical significance was defined as $\mathrm{p}<0.05$. Tests were conducted 2 -sided and values are represented as mean \pm SD unless otherwise specified. Categorical variables were compared using the $\chi^{2}$ test. Normal distribution of continuous data was assessed by the KolmogorovSmirnov test. Unpaired two-sided Student's t-test was used to compare normally distributed continuous data between two groups and for multiple groups with the one-way analysis of variance test. Pearson's correlation coefficient was used to calculate correlation between platelet inhibition and on-treatment aggregation and Spearman's correlation coefficient was used to correlate on-treatment platelet aggregation between different agonists.

\section{RESULTS}

Baseline characteristics of the study subjects are described in table 1 . Among the 55 patients included in this study, $39(71 \%)$ were wild-type homozygous for the CYP2C19*2 allelic 
variant $(* 1 / * 1), 15(27 \%)$ were heterozygous $* 2$ allele carriers $(* 1 / * 2)$, and 1 patient $(2 \%)$ was homozygous $* 2$ allele carrier $(* 2 / * 2)$. No significant deviation from Hardy-Weinberg equilibrium was observed ( $\mathrm{p}=0.73$ ) for CYP2C19*2 genotypes. There were no CYP2C19*3 alleles detected in the study population which is consistent with the very rare frequency of this loss-of-function allele in subjects of European and African descent [24].

Platelet aggregation induced by ADP demonstrated wide interindividual variability during therapy with clopidogrel (Table 2, Figure 1). Among patients who were not pretreated with clopidogrel prior to receiving $600 \mathrm{mg}$ loading dose and who had a baseline platelet aggregation sample available for analysis, $\%$ platelet inhibition was calculated, defined as $\%$ change in platelet aggregation from baseline. Platelet inhibition (\%) correlated well with ADP induced on-treatment platelet aggregation 16-24 hours after clopidogrel loading dose $(\mathrm{r}=-0.904 ; \mathrm{p}<0.0001 ; \mathrm{n}=36)$

Subjects were grouped according to quartiles of maximal platelet aggregation induced by 20 $\mu \mathrm{M}$ ADP at 16-24 hours after $600 \mathrm{mg}$ clopidogrel loading dose. We defined responders as the subjects in the lowest quartile of on-treatment platelet aggregation and non-responders in the highest quartile of on-treatment platelet aggregation. The distribution of clinical variables across quartiles of on-treatment platelet aggregation is shown in table 1. Although there was a trend towards lower prevalence of CYP2C19 $* 2$ carriers in the lowest quartile as compared to the remaining quartiles, the distribution of genotypes was not statistically significant different among quartiles $(\mathrm{p}=0.17$, Table 1$)$. On treatment platelet aggregation induced by ADP $20 \mu \mathrm{M}$ was not significantly higher in carriers of CYP2C19*2 than compared to non-carriers $(41.8 \pm 18 \%$ vs. $39.1 \pm 17 \%, \mathrm{p}=0.87 ; 95 \%$ confidence interval (CI) of difference: $-7.5 \%$ to $12.8 \%$ ).

Maximal on-treatment platelet aggregation induced by ADP $20 \mu \mathrm{M}$ and TRAP varied according to quartiles (table 2). Maximal platelet aggregation induced by TRAP $15 \mu \mathrm{M}$ and $25 \mu \mathrm{M}$ was significantly lower among clopidogrel responders, i.e. subjects in the lowest quartile of ADP induced aggregation as compared to clopidogrel non-responders, i.e. subjects in the highest quartile of ADP induced aggregation (Table 2). On-treatment platelet aggregation induced by ADP $20 \mu \mathrm{M}$ correlated with TRAP $15 \mu \mathrm{M}$ and TRAP $25 \mu \mathrm{M}$ induced aggregation $(r=0.56 ; p<0.0001$ and $r=0.55 ; p<0.0001$; Figure 1). Also, platelet inhibition (\%) correlated with TRAP $15 \mu \mathrm{M}$ and TRAP $25 \mu \mathrm{M}$ induced aggregation 16-24 hours after clopidogrel loading dose $(\mathrm{r}=-0.45 ; \mathrm{p}=0.07$ and $\mathrm{r}=-0.4 ; \mathrm{p}=0.02$; Figure 1$)$.

\section{DISCUSSION}

Dual antiplatelet therapy with aspirin and a platelet P2Y12 inhibitor is considered standard of therapy to prevent recurrent myocardial infarction and stent thrombosis after coronary stenting. Clopidogrel, the most commonly used P2Y12 inhibitor is subject to a wide variability in active metabolite generation and subsequent pharmacodynamic response [1-9]. Reduced function genetic polymorphisms of CYP2C19 $(* 2)$ have been associated with increased ischemic events and stent thrombosis after coronary stenting [5-9]. Platelet PAR-1 inhibitors have been developed for use in prevention of cardiovascular events in light of the prominent role of PAR-1 mediated platelet activation by thrombin [11-19]. Voraxapar, the first in its class to complete phase 3 studies has been examined in the TRACER trial where it was added to standard dual antiplatelet therapy with clopidogrel and aspirin in patients with acute coronary syndromes [18]. Subjects who were randomized to voraxapar were found to have significantly increased risk of moderate to severe bleeding (HR 1.35; 95\% CI, 1.16 to 1.58), including intracranial hemorrhage (HR 3.39; $95 \% \mathrm{CI}, 1.78$ to 6.45 ; $\mathrm{p}<0.001$ ), with a non-significant reduction in the composite primary endpoint of cardiovascular death, myocardial infarction, stroke, recurrent ischemia with rehospitalization, or urgent coronary 
revascularization (HR 0.92; 95\% CI 0.85 to $1.01 ; \mathrm{p}=0.07$ ) [18]. The composite of cardiovascular death, myocardial infarction, and stroke however was significantly reduced in subjects randomized to voraxapar (HR 0.89; $95 \% \mathrm{CI}, 0.81$ to $0.98 ; \mathrm{p}=0.02)$ [18]. The results of our pharmacodynamic study document a significant correlation of platelet aggregation induced by PAR-1 stimulation with on-treatment aggregation induced by ADP during therapy with clopidogrel. Clopidogrel responders defined as subjects in the lowest quartile of ADP induced on-treatment platelet aggregation showed significantly lower maximal PAR-1 mediated platelet aggregation as compared to subjects in the highest quartile (clopidogrel non-responders). There appeared to be correlation between maximal PAR-1 mediated platelet aggregation induced by TRAP, maximal platelet aggregation induced by ADP and \% platelet inhibition (Figure 1). The higher levels of maximal platelet aggregation observed with $25 \mu \mathrm{M}$ TRAP across quartiles as compared to the $15 \mu \mathrm{M}$ TRAP agonist dose, suggest that the relative inhibition of TRAP induced platelet aggregation by clopidogrel may at least partially be overcome with higher doses of PAR-1 agonist. In our current study, CYP2C19 $* 2$ carrier status was not significantly associated with increased ontreatment ADP induced platelet aggregation, as previously published $[5,6,25,26]$. As documented by Shuldiner et al., CYP2C19*2 genotype status may account for only a limited degree of variation ( 12\%) in clopidogrel response [25]. While on-treatment platelet aggregation in carriers of CYP2C19*2 was slightly higher than in non-carriers in our study, it was lower than previously published $[25,26]$. The wide $95 \% \mathrm{CI}$ of the difference between genotypes is reflective of the limited power of our study to reduplicate the previously published findings due to the relatively small sample size.

In addition to differences in active clopidogrel metabolite generation, other hypotheses have been postulated to explain the extent of variation in ADP induced platelet reactivity during therapy with clopidogrel [27]. Using both mouse and human platelets, Haberstock-Debic et al. demonstrated upregulation of previously intracellular, functional P2Y12 receptors to the platelet surface after stimulation with TRAP during treatment with clopidogrel. These findings suggest the presence of an intracellular pool of P2Y12 receptors that may not be antagonized by a transient rise of extracellular clopidogrel active metabolite with daily clopidogrel dosing, but can be upregulated and become functional after stimulation of platelets with TRAP [27]. These data suggest an interplay between platelet activation though PAR-1 and possible recruitment of non-inhibited P2Y12 receptors to the surface of platelets [27]. Increased platelet activation after stimulation with ADP in subjects treated with clopidogrel has been documented during acute coronary syndromes, a clinical scenario that is generally associated with thrombosis and continued thrombin generation [28]. Concentrations of thrombin at sites of thrombus formation may be as high as $140 \mathrm{nM}$, higher than the EC50 concentrations for platelet activation of both PAR-1 and PAR-4 receptors $[12,13,29]$. However, PAR-4 is significantly less abundant on human platelets as compared to PAR-1, with an EC50 concentration that is $\sim 50$ fold higher than that of PAR-1 $[12,13]$. PAR-1 is more likely to become activated at lower levels of thrombin, and is thus considered the predominant mediator of thrombin induced aggregation in humans $[11,13,14$, 30].

Our data is consistent with the observation that ADP and thrombin play a synergistic role in platelet activation [30,31]. TRAP induces PAR-1 activation and results in ADP release which further facilitates platelet activation by autocrine/paracrine pathway [30]. In clopidogrel non-responders, increased TRAP-induced platelet activation may have been observed due to lack of protection from activation of P2Y12 receptor. In contrast, clopidogrel responders may have had less TRAP-induced platelet activation because P2Y12 mediated pathways were inhibited by clopidogrel. This is supported by data from Cornelissen et al. who demonstrated augmentation of antithrombotic effects by combining partial attenuation of ADP and thrombin signalling in a murine $\mathrm{FeCl}_{3}$ carotid injury model 
using complete and partial PAR-3, PAR-4, and P2Y12 knockout mice [30]. Their findings also suggested that inhibition of $\mathrm{P} 2 \mathrm{Y} 12$ signalling is more relevant in prolonging hemostasis than inhibition of PAR signalling measured by tail bleeding times and surgical blood loss in mice. The authors suggested that levels of thrombin produced during hemostasis may be relatively high, and that a low level of thrombin signalling may be sufficient for adequate hemostasis, such as during pharmacological PAR-1 inhibition [30]. The presence of PAR-4 receptors capable of inducing aggregation in the presence of PAR-1 inhibition has been suggested to serve as a safety net for hemostasis when higher levels of thrombin are generated [30].

In human subjects, activation of P2Y12 receptor has been demonstrated to enhance procoagulant activity, further illustrating the close interconnection between coagulation and platelet aggregation $[32,33]$. Our findings are also consistent with data from a similar study by Gremmel et al. who demonstrated correlation of TRAP induced platelet aggregation with aggregation induced by ADP in subjects treated with clopidogrel, but found only weak correlation of TRAP induced aggregation with P2Y12 inhibition measured by vasodilatorstimulated phosphoprotein phosphorylation assay (VASP) [23]. While results of platelet aggregation substudies or genetic analysis from the TRACER trial have not been published, we have to assume that clopidogrel non-response or reduced function CYP2C19 genotype status would be associated with similarly increased rates of ischemic events as observed in prior acute coronary syndrome studies in patients treated with aspirin and clopidogrel. Further studies may be necessary to specifically evaluate the effect of additional PAR-1 inhibition with voraxapar in clopidogrel non-responders with ACS and high residual platelet reactivity to ADP. Addition of PAR-1 inhibitors in clopidogrel non-responders may be a possible therapeutic strategy to reduce risk of ischemic events after coronary stenting and acute coronary syndromes while potentially avoiding adverse bleeding events in clopidogrel responders.

Limitations of our study include a relatively small sample size and lack of pharmacokinetic analysis to detect differences in active clopidogrel metabolite concentrations. Although considered gold standard for measuring platelet aggregation and clopidogrel platelet inhibition, light transmittance aggregometry is subject to operator variability, and ontreatment platelet aggregation may not be a direct reflection of P2Y12 receptor inhibition by active clopidogrel metabolites.

In conclusion, our findings support a relative, but not complete reduction of PAR-1 mediated aggregation in clopidogrel responders with low residual platelet aggregation induced by ADP and higher PAR-1 mediated aggregation in clopidogrel non-responders. This may suggest a relative protection from thrombin induced platelet aggregation in subjects who are clopidogrel responders and relative lack thereof in subjects with high ADP induced residual platelet reactivity on clopidogrel. The findings of this study support the hypothesis that PAR-1 mediated aggregation is dependent on the magnitude of clopidogrel response in patients treated with clopidogrel and aspirin.

\section{Acknowledgments}

This study was supported in part, by the Indiana Clinical and Translational Sciences Institute funded, in part by Grant Number (RR025761) from the National Institutes of Health, National Center for Research Resources, Clinical and Translational Sciences Award, and internal funding from the Department of Medicine, Indiana University School of Medicine, Indianapolis. 


\section{REFERENCES}

1. Angiolillo DJ, Fernandez-Ortiz A, Bernardo E, Alfonso F, Macaya C, Bass TA, Costa MA. Variability in individual responsiveness to clopidogrel: clinical implication, management, and future perspectives. J Am Coll Cardiol. 2007; 49:1505-16. [PubMed: 17418288]

2. Gurbel PA, Bliden KP, Guyer K, Cho PW, Zaman KA, Kreutz RP, Bassi AK, Tantry US. Platelet Reactivity in Patients and Recurrent Events Post-Stenting: Results of the PREPARE POSTSTENTING Study. J Am Coll Cardiol. 2005; 46(10):1820-1826. [PubMed: 16286165]

3. Buonamici P, Marcucci R, Migliorini A, Gensini GF, Santini A, Paniccia R, Moschi G, Gori AM, Abbate R, Antoniucci D. Impact of platelet reactivity after clopidogrel administration on drugeluting stent thrombosis. J Am Coll Cardiol. 2007; 49:2312-7. [PubMed: 17572245]

4. Breet NJ, van Werkum JW, Bouman HJ, Kelder JC, Ruven HJ, Bal ET, Deneer VH, Harmsze AM, van der Heyden JA, Rensing BJ, Suttorp MJ, Hackeng CM, ten Berg JM. Comparison of Platelet Function Tests in Predicting Clinical Outcome in Patients Undergoing Coronary Stent Implantation. JAMA. 2010; 303:754-62. [PubMed: 20179285]

5. Trenk D, Hochholzer W, Fromm MF, Chialda LE, Pahl A, Valina CM, Stratz C, Schmiebusch P, Bestehorn HP, Büttner HJ, Neumann FJ. Cytochrome P450 2C19 681G>A polymorphism and high on-clopidogrel platelet reactivity associated with adverse 1-year clinical outcome of elective percutaneous coronary intervention with drug-eluting or bare-metal stents. J Am Coll Cardiol. 2008; 51:1925-34. [PubMed: 18482659]

6. Mega JL, Close SL, Wiviott SD, Shen L, Hockett RD, Brandt JT, Walker JR, Antman EM, Macias W, Braunwald E, Sabatine MS. Cytochrome P-450 polymorphisms and response to clopidogrel. N Engl J Med. 2009; 360:354-62. [PubMed: 19106084]

7. Collet JP, Hulot JS, Pena A, Villard E, Esteve JB, Silvain J, Payot L, Brugier D, Cayla G, Beygui F, Bensimon G, Funck-Brentano C, Montalescot G. Cytochrome P450 2C19 polymorphism in young patients treated with clopidogrel after myocardial infarction: a cohort study. Lancet. 2009; 373:30917. [PubMed: 19108880]

8. Simon T, Verstuyft C, Mary-Krause M, Quteineh L, Drouet E, Méneveau N, Steg PG, Ferrières J, Danchin N, Becquemont L. French Registry of Acute ST-Elevation and Non-ST-Elevation Myocardial Infarction (FAST-MI) Investigators. Genetic determinants of response to clopidogrel and cardiovascular events. N Engl J Med. 2009; 360:363-75. [PubMed: 19106083]

9. Mega JL, Simon T, Collet JP, Anderson JL, Antman EM, Bliden K, Cannon CP, Danchin N, Giusti B, Gurbel P, Horne BD, Hulot JS, Kastrati A, Montalescot G, Neumann FJ, Shen L, Sibbing D, Steg PG, Trenk D, Wiviott SD, Sabatine MS. Reduced-function CYP2C19 genotype and risk of adverse clinical outcomes among patients treated with clopidogrel predominantly for PCI: a meta-analysis. JAMA. 2010; 304:1821-30. [PubMed: 20978260]

10. Borissoff JI, Spronk HM, ten Cate H. The hemostatic system as a modulator of atherosclerosis. N Engl J Med. 2011; 364:1746-60. [PubMed: 21542745]

11. Kahn ML, Zheng YW, Huang W, Bigornia V, Zeng D, Moff S, Farese RV, Tam C, Coughlin SR. A dual thrombin receptor system for platelet activation. Nature. 1998; 394:690-694. [PubMed: 9716134]

12. Vu TK, Hung DT, Wheaton VI, Coughlin SR. Molecular cloning of a functional thrombin receptor reveals a novel proteolytic mechanism of receptor activation. Cell. 1991; 64:1057-68. [PubMed: 1672265]

13. Xu WF, Andersen H, Whitmore TE, Presnell SR, Yee DP, Ching A, Gilbert T, Davie EW, Foster DC. Cloning and characterization of human protease-activated receptor 4. Proc Natl Acad Sci USA. 1998; 95:6642-6646. [PubMed: 9618465]

14. Andersen H, Greenberg DL, Fujikawa K, Xu W, Chung DW, Davie EW. Protease-activated receptor 1 is the primary mediator of thrombin-stimulated platelet procoagulant activity. Proc Natl Acad Sci U S A. 1999; 96(20):11189-93. [PubMed: 10500152]

15. Trumel C, Payrastre B, Plantavid M, Hechler B, Viala C, Presek P, Martinson EA, Cazenave JP, Chap H, Gachet C. A key role of adenosine diphosphate in the irreversible platelet aggregation induced by the PAR1-activating peptide through the late activation of phosphoinositide 3-kinase. Blood. 1999; 94(12):4156-65. [PubMed: 10590060] 
16. Jakubowski JA, Payne DC, Li YG, Brandt JT, Small DS, Farid NA, Salazar DE, Winters KJ. The use of the VerifyNow P2Y12 point-of-care device to monitor platelet function across a range of P2Y12 inhibition levels following prasugrel and clopidogrel administration. Thromb Haemost. 2008; 99:409-15. [PubMed: 18278193]

17. Angiolillo D, Capranzano P. Pharmacology of emerging novel platelet inhibitors. Am Heart J. 2008; 156:S10-S15. [PubMed: 18657681]

18. Tricoci P, Huang Z, Held C, Moliterno DJ, Armstrong PW, Van de Werf F, White HD, Aylward PE, Wallentin L, Chen E, Lokhnygina Y, Pei J, Leonardi S, Rorick TL, Kilian AM, Jennings LH, Ambrosio G, Bode C, Cequier A, Cornel JH, Diaz R, Erkan A, Huber K, Hudson MP, Jiang L, Jukema JW, Lewis BS, Lincoff AM, Montalescot G, Nicolau JC, Ogawa H, Pfisterer M, Prieto JC, Ruzyllo W, Sinnaeve PR, Storey RF, Valgimigli M, Whellan DJ, Widimsky P, Strony J, Harrington RA, Mahaffey KW, the TRACER Investigators. Thrombin-Receptor Antagonist Vorapaxar in Acute Coronary Syndromes. N Engl J Med. 2011 published online November 13, 2011.

19. O'Donoghue ML, Bhatt DL, Wiviott SD, Goodman SG, Fitzgerald DJ, Angiolillo DJ, Goto S, Montalescot G, Zeymer U, Aylward PE, Guetta V, Dudek D, Ziecina R, Contant CF, Flather MD, LANCELOT-ACS Investigators. Safety and tolerability of atopaxar in the treatment of patients with acute coronary syndromes: the lessons from antagonizing the cellular effects of ThrombinAcute Coronary Syndromes Trial. Circulation. 2011; 123(17):1843-53. [PubMed: 21502577]

20. Kreutz RP, Tantry US, Bliden KP, Gurbel PA. Inflammatory changes during the 'common cold' are associated with platelet activation and increased reactivity of platelets to agonists. Blood Coagul Fibrinolysis. 2007; 18:713-8. [PubMed: 17982310]

21. Kreutz RP, Alloosh M, Mansour K, Neeb Z, Kreutz Y, Flockhart DA, Sturek M. Morbid obesity and metabolic syndrome in Ossabaw miniature swine are associated with increased platelet reactivity. Diabetes Metab Syndr Obes. 2011; 4:99-105. [PubMed: 21660293]

22. Jennings, LK.; McCabe-White, M.; Michelson, AD. Platelets. Elsevier; Oxford, UK: 2007. Platelet Aggregation; p. 503

23. Gremmel T, Calatzis A, Steiner S, Kaider A, Seidinger D, Koppensteiner R, Kopp CW, Panzer S. Is TRAP-6 suitable as a positive control for platelet reactivity when assessing response to clopidogrel. Platelets. 2010; 21(7):515-521. [PubMed: 20624009]

24. [accessed Jan 31st, 2012] www.hapmap.org

25. Shuldiner AR, O'Connell JR, Bliden KP, Gandhi A, Ryan K, Horenstein RB, Damcott CM, Pakyz R, Tantry US, Gibson Q, Pollin TI, Post W, Parsa A, Mitchell BD, Faraday N, Herzog W, Gurbel PA. Association of cytochrome P450 2C19 genotype with the antiplatelet effect and clincal efficacy of clopidogrel. JAMA. 2009; 302:849-858. [PubMed: 19706858]

26. Rideg O, Komócsi A, Magyarlaki T, Tokés-Füzesi M, Miseta A, Kovács GL, Aradi D. Impact of genetic variants on post-clopidogrel platelet reactivity in patients after elective percutaneous coronary intervention. Pharmacogenomics. 2011; 12(9):1269-80. [PubMed: 21806387]

27. Haberstock-Debic H, Andre P, Mills S, Phillips DR, Conley PB. A Clopidogrel-Insensitive Inducible Pool of P2Y12 Receptors Contributes to Thrombus Formation: Inhibition by Elinogrel, a Direct-Acting, Reversible P2Y12 Antagonist. JPET. 2011; 339:54-61.

28. Sibbing D, von Beckerath O, Schömig A, Kastrati A, von Beckerath N. Platelet function in clopidogrel-treated patients with acute coronary syndrome. Blood Coagul Fibrinolysis. 2007; 18:335-9. [PubMed: 17473574]

29. Walz DA, Anderson GF, Ciaglowski RE, Aiken M, Fenton JW. Thrombin elicited contractile responses of aortic smooth muscle. Proc Soc Exp Biol Med. 1985; 180:518-526. [PubMed: 4080701]

30. Cornelissen I, Palmer D, David T, Wilsbacher L, Concengo C, Conley P, Pandey A, Coughlin SR. Roles and interactions among protease-activated receptors and P2ry 12 in hemostasis and thrombosis. Proc Natl Acad Sci USA. 2010; 107(43):18605-10. [PubMed: 20930120]

31. Nylander S, Mattsson C, Ramström S, Lindahl TL. Synergistic action between inhibition of $\mathrm{P} 2 \mathrm{Y} 12 / \mathrm{P} 2 \mathrm{Y} 1$ and P2Y12/thrombin in ADP- and thrombin-induced human platelet activation. British Journal of Pharmacology. 2004; 142:1325-31. [PubMed: 15265806] 
32. Van der Meijden P, Feijge M, Giesen P, Huijberts M, van Raak L, Heemskerk J. Platelet P2Y12 receptors enhance signalling towards procoagulant activity and thrombin generation. A study with healthy subjects and patients at thrombotic risk. Thrombosis and Haemostasis. 2005; 93:1010-201.

33. Shankar H, Garcia A, Prabhakar J, Kim S, Kunapuli SP. P2Y12 receptor-mediated potentiation of thrombin-induced thromboxane A2 generation in platelets occurs through regulation of Erk1/2 activation. Journal of Thrombosis and Haemostasis. 2006; 4:638-47. [PubMed: 16460446] 
A
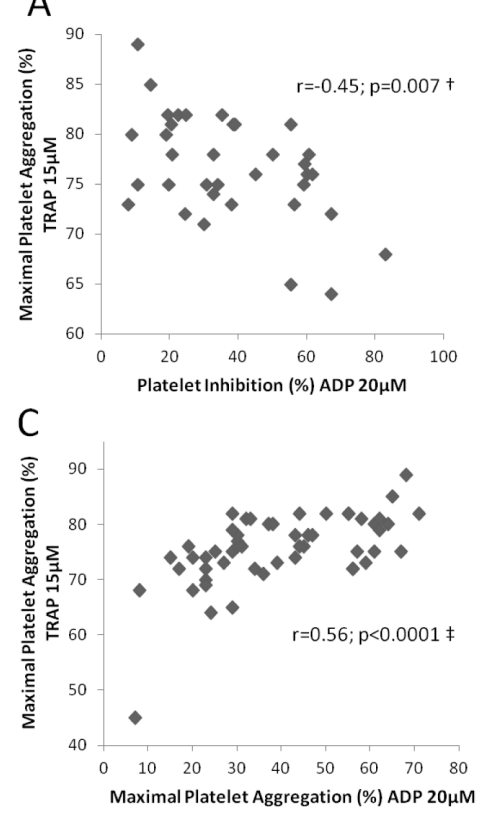

B
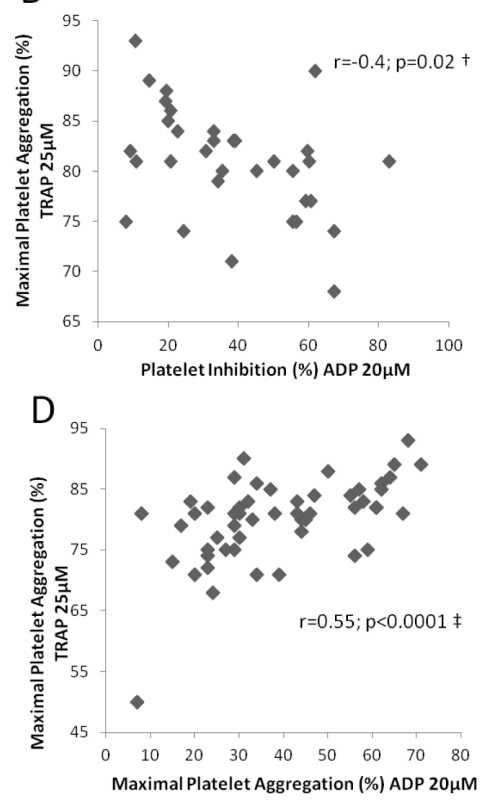

Figure 1.

Scatterplot of maximal platelet aggregation induced by TRAP $15 \mu \mathrm{M}$ (Panel A) and TRAP $25 \mu \mathrm{M}$ (Panel B) vs. \% platelet inhibition (defined as \% change from ADP $20 \mu \mathrm{M}$ aggregation baseline at 16-24 hours after clopidogrel loading dose) in subjects not previously exposed to clopidogrel. Scatterplot of maximal platelet aggregation induced by TRAP $15 \mu \mathrm{M}$ (Panel C) and TRAP $25 \mu \mathrm{M}$ (Panel D) vs. maximal platelet aggregation induced by ADP $20 \mu \mathrm{M}$ 16-24 hours after clopidogrel loading dose. Pearson's ( $\dagger$ ) and Spearman’s ( ) correlation coefficientTotal 


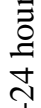

bे

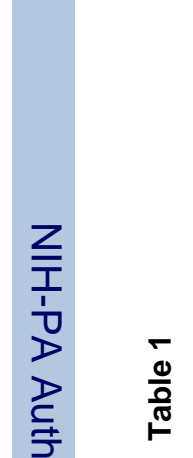

U घ $\sum^{\pi}$

\begin{tabular}{|c|c|c|c|c|c|c|c|c|c|c|c|c|c|c|c|}
\hline 裳 & 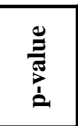 & $\begin{array}{l}+1 \\
0 \\
\infty \\
0\end{array}$ & 苦 & $=$ & ta & r. & ty & th & in & $\stackrel{+}{+\infty}$ & $\begin{array}{l}+\infty \\
\stackrel{\infty}{0} \\
\stackrel{0}{0}\end{array}$ & ta & 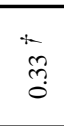 & to & $\stackrel{1}{a}$ \\
\hline 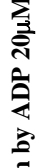 & 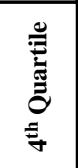 & $\begin{array}{l}\infty \\
+1 \\
+ \\
\text { dे }\end{array}$ & $\begin{array}{l}n \\
+1 \\
m \\
m \\
m\end{array}$ & $\frac{8}{\frac{8}{m}}$ & $\frac{\hat{c}}{\grave{a}}$ & $\begin{array}{l}\hat{\hat{d}} \\
\stackrel{m}{a}\end{array}$ & $\begin{array}{l}\stackrel{\sqrt[n]{Z}}{n} \\
\underset{n}{N}\end{array}$ & $\frac{\widehat{\widehat{d}}}{\stackrel{m}{\infty}}$ & $\begin{array}{l}\stackrel{0}{\infty} \\
\stackrel{\infty}{a} \\
\stackrel{\Xi}{a}\end{array}$ & $\begin{array}{l}\stackrel{\tilde{\alpha}}{\infty} \\
\stackrel{m}{\Xi} \\
\Xi\end{array}$ & $\begin{array}{l}\stackrel{n}{=} \\
\stackrel{m}{a}\end{array}$ & $\begin{array}{l}\underset{f}{d} \\
\stackrel{n}{i}\end{array}$ & $\begin{array}{l}\frac{0}{d} \\
\frac{m}{b}\end{array}$ & 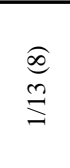 & $a+0$ \\
\hline 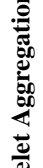 & 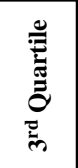 & $\begin{array}{l}= \\
+1 \\
+1 \\
+\end{array}$ & $\begin{array}{l}a \\
+1 \\
\infty \\
\stackrel{\lambda}{0}\end{array}$ & $\begin{array}{l}\frac{f}{d} \\
\frac{ \pm}{\sigma}\end{array}$ & $\underset{\Xi}{\stackrel{\Xi}{\Xi}}$ & $\begin{array}{l}\underset{f}{d} \\
\frac{d}{\sigma}\end{array}$ & $\begin{array}{l}\widehat{o} \\
\stackrel{t}{a}\end{array}$ & 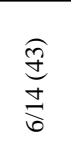 & 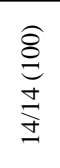 & 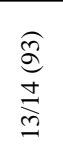 & $\begin{array}{l}\hat{d} \\
\vec{\partial} \\
\vec{f}\end{array}$ & $\begin{array}{l}\underset{\Xi}{\Xi} \\
\stackrel{+}{\Xi}\end{array}$ & 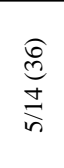 & $\underset{\underset{d}{\stackrel{J}{J}}}{\underset{J}{J}}$ & $\sigma \nabla-$ \\
\hline 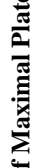 & 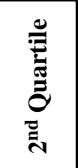 & 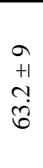 & $\begin{array}{l}\infty \\
+1 \\
b \\
\text { i } \\
m\end{array}$ & $\begin{array}{l}0 \\
\stackrel{D}{\infty} \\
\stackrel{\Xi}{\Xi}\end{array}$ & $\begin{array}{l}E \\
\stackrel{5}{\Xi}\end{array}$ & 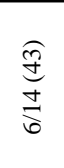 & 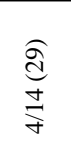 & $\begin{array}{l}\underset{\mathrm{d}}{+} \\
\stackrel{+}{f}\end{array}$ & 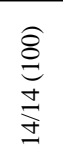 & 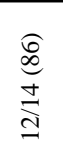 & 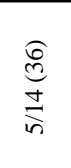 & $\begin{array}{l}\widehat{尺} \\
\stackrel{n}{0} \\
\underset{N}{*}\end{array}$ & 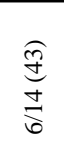 & 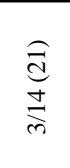 & $9+0$ \\
\hline 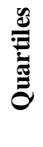 & 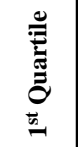 & $\begin{array}{l}0 \\
+1 \\
+1 \\
\stackrel{8}{0}\end{array}$ & $\begin{array}{l}0 \\
+1 \\
\tilde{y} \\
\stackrel{n}{0}\end{array}$ & $\begin{array}{l}\widehat{E} \\
\text { I } \\
\Xi\end{array}$ & $\begin{array}{l}\stackrel{d}{d} \\
\frac{d}{f}\end{array}$ & $\begin{array}{l}\widehat{\sigma} \\
\stackrel{\sigma}{\sigma}\end{array}$ & $\underset{\underset{d}{\stackrel{J}{J}}}{\underset{J}{J}}$ & $\begin{array}{l}\underset{6}{6} \\
\underset{i}{*}\end{array}$ & $\begin{array}{l}\hat{\mathrm{g}} \\
\stackrel{\mathrm{J}}{\mathrm{J}}\end{array}$ & 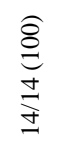 & 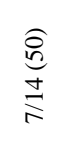 & $\begin{array}{l}\widehat{\overparen{J}} \\
\frac{\mathbb{J}}{\sigma}\end{array}$ & $\begin{array}{l}\widehat{\vartheta} \\
\frac{\mathbb{J}}{\sigma}\end{array}$ & 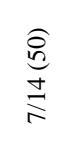 & $=m o$ \\
\hline & 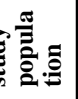 & $\begin{array}{l}\overrightarrow{+} \\
+ \\
\tilde{\sigma}\end{array}$ & 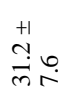 & 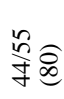 & 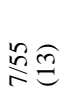 & 点 & $\frac{n}{\infty} \cong$ & 点 & 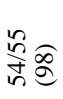 & in & $\begin{array}{l}\stackrel{n}{\infty} \widehat{\infty} \\
\stackrel{\infty}{\infty}\end{array}$ & $\begin{array}{l}\stackrel{n}{2} 6 \\
m \\
m\end{array}$ & 을 & $\stackrel{n}{\stackrel{n}{g}} \underset{d}{d}$ & $\dot{m}=$ \\
\hline & 童 & 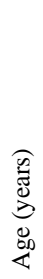 & 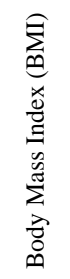 & 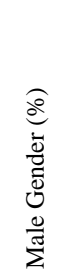 & 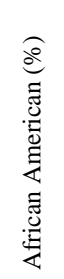 & 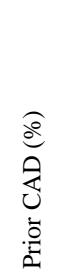 & 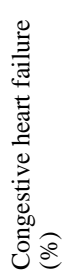 & 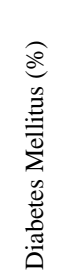 & 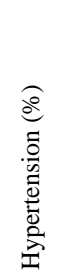 & 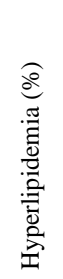 & 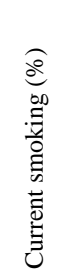 & 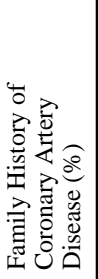 & 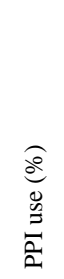 & 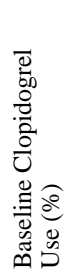 & 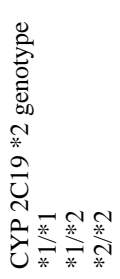 \\
\hline
\end{tabular}




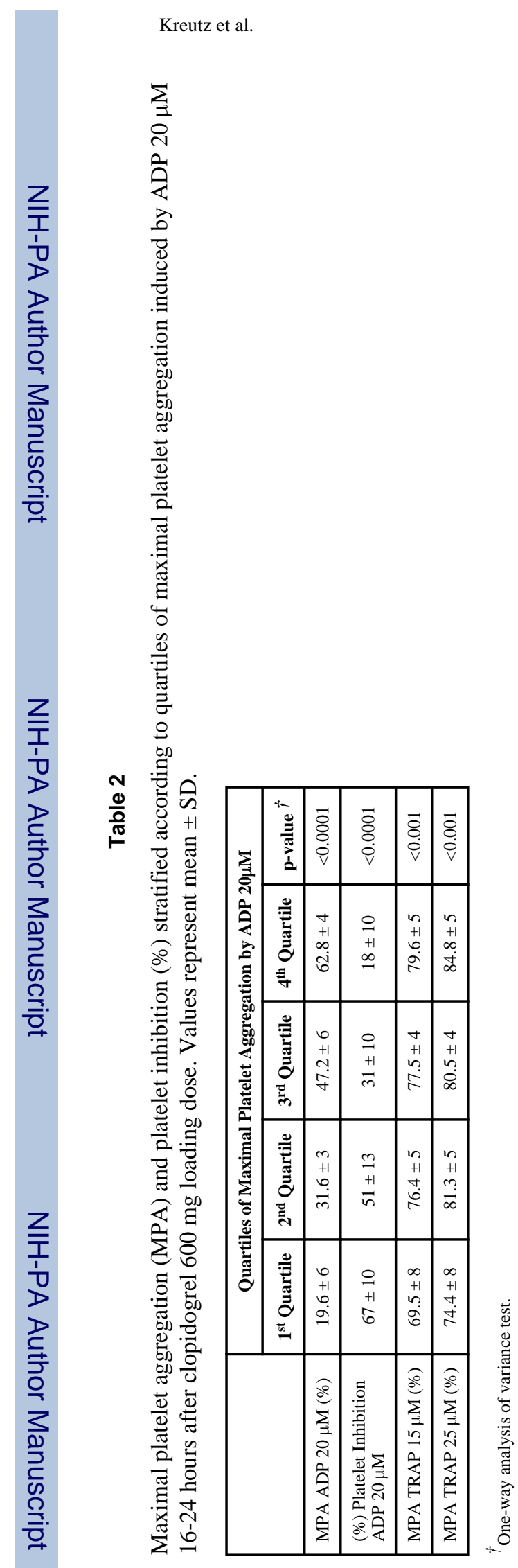

Page 13 